Zabytkoznawstwo i Konserwatorstwo XLIV, Toruń 2013

\author{
Józef Poklewski
}

Wydział Sztuk Pięknych UMK

\title{
Wileńskie Trzy Krzyże
}

$\mathrm{P}$ rzechodząc przez zadbany i bardzo starannie utrzymany komunalny cmentarz w Giżycku, trudno nie zauważyć nagrobka Michaliny Narwojsz (1900-1983), którego zwieńczenie stanowi pełnoplastyczna miniaturka wileńskiego pomnika Trzech Krzyży autorstwa Antoniego Wiwulskiego (1877-1919). Jak wynika z umieszczonej na steli daty zgonu spoczywającej pod ta płyta, nagrobek został wzniesiony w czasie, gdy wileńskie krzyże realnie nie istniały, zostały bowiem wysadzone w powietrzne w wyniku decyzji władz Litwy Radzieckiej, a świadomość ich realnego niegdyś istnienia i roli w powstaniu Wilna utrwalały jedynie stare fotografie i wdzięczna pamięć ludzi pochodzących z „miłego miasta”. Wyeksponowanie wileńskich Trzech Krzyży w zwieńczeniu wspomnianego nagrobka wynika, jak należy sądzić, z chęci zamanifestowania przez jego fundatorów związku zmarłej z miejscem swego pochodzenia. Nie należy bowiem zapominać, że górujace nad miastem Trzy Krzyże zarówno dla mieszkańców Wilna, jak i wilnian żyących w diasporze sa tym samym co wieża Eiffla dla paryżan czy Big Ben dla londyńczyków - zarówno symbolem, jak i wizytówką miasta. Przy tym w wypadku wspomnianych krzyży tradycyjnie silnie związany z pomnikiem jest jego aspekt religijny. Krzyże Wiwulskiego użyte jako ozdoba nagrobka wyraźnie świadczą o głębokim i mocnym przywiązaniu repatriantów do Wilna, które musieli opuścić nie z własnej woli, lecz w wyniku represyjnych uwarunkowań politycznych. Być może na wybór Trzech Krzyży jako motywu wieńczącego, także w wypadku kilku innych nagrobków na tym cmentarzu, mogła wpływać przyniesiona na Mazury przez wyzutych z ojcowizny repatriantów żywa w Wilnie w okresie dwudziestolecia międzywo- 
jennego opinia o graniczącej ze świętościa pobożności i religijności Wiwulskiego, a także o jego patriotyzmie potwierdzonym zakończonym śmiercią udziałem w antybolszewickiej samoobronie w styczniu 1919 roku ${ }^{1}$.

Wieńczące szczyt najwyższego wzgórza w otaczającym miasto od północnego wschodu paśmie i stanowiące pionową dominantę panoramy Wilna Trzy Krzyże zostały wysadzone w powietrze 30 maja $1950 \mathrm{roku}^{2}$ na wieść o mającej nastąpić wizycie ówczesnego ministra spraw zagranicznych ZSRR Wiaczesława Mołotowa na Litwie. Wizyta nie doszła do skutku. Pomnik został zniszczony. Wysadzenie w powietrze dominujących nad miastem krzyży było w pełni zgodne $z$ ateistyczną ideologia Litwy radzieckiej. Dopiero rozpad Związku Radzieckiego, w wyniku którego nastapiło odzyskanie niepodległości przez tworzace go republiki, doprowadził do zmian systemowych. Wraz z niepodległością Litwa uzyskała możliwość czynienia starań o rekonstrukcję tego tak znaczącego dla Wilna pomnika. Akcja ta wzbudziła zainteresowanie oczywiście i w Polsce. W sierpniowym numerze „Tygodnika Powszechnego” z 1988 roku ukazała się wzmianka zatytułowana „Odbudować Trzy Krzyże Wileńskie”, sygnowana nazwiskiem znanego i zasłużonego badacza kultury i sztuki wileńskiej, a także tłumacza literatury litewskiej, prof. Mieczysława Jackiewicza z Olsztyna ${ }^{3}$, w której informował o tym, że: „ostatnio (23 VII br.) na łamach tygodnika «Literatura ir Menas» (Literatura i Sztuka) ukazała się propozycja, by odbudować Trzy Krzyże projektu A. Wiwulskiego, które zburzono w $1951 \mathrm{roku}^{4}$. Odbudowane Trzy Krzyże w Wilnie miałyby stanowić pomnik poświęcony ofiarom stalinizmu na Litwie”. Ten sam autor w listopadowym numerze „Tygodnika” donosił, że: „w dniu 22 października br. odbył się w Wilnie założycielski zjazd Litewskiego Ruchu na Rzecz Przebudowy «Sajudis»". Podczas zjazdu wystapił znany pierwszy sekretarz KC KPL, Algirdas Mykolas Brazauskas (Olgierd Mikołaj Brzozowski), który w przemówieniu m.in. powiedział:

1 J. Poklewski, Antoni Wiwulski twórca niestusznie zapomniany. Wilno i kresy pótnocno-nschodnie, t. 2: Kultura i trwanie, red. E. Felisiak i A. Kisielewska, Białystok 1996, s. 169-190.

2 N. Lukšionytè-Tolvaišienè, Antanas Vivulskis 1877-1919 tradicïu ir modernumo dermé, Vilnius 2002, s. 70.

3 M. Jackiewicz, Odbudować Tray Krayże Wileńskie, „Tygodnik Powszechny” 1988, nr 33, s. 5 .

${ }^{4}$ Por. N. Lukšionytè-Tolvaišienè, op. cit., s. 70. 
„kierownictwo Republiki w całej pełni popiera propozycję społeczności, aby stworzyć i wznieść w najbliższym czasie pomnik ku czci ofiar represji stalinizmu. Jesteśmy mocno zdecydowani uczynić wszystko, aby do czerwca przyszłego roku został wskrzeszony pomnik Trzech Krzyży w Wilnie"5.

Projektant i główny inicjator wykonanej społecznie rekonstrukcji wileńskich Trzech Krzyży architekt Henrikas Šilgalis dzięki swej pozycji i sile perswazji zdołał przekonać decydentów, że pomnik ten sam ,jest swego rodzaju ofiara stalinizmu” i że jego „odbudowa nie powinna łączyć się z intencją uczczenia innych wydarzeń niż te, którym był poświęcony pierwotnie, gdyż byłoby to nieuczciwe wobec twórcy pomnika"'. Zrekonstruowany pomnik powiela kształt, jaki przed laty nadał mu Antoni Wiwulski i tylko dla mocniejszej dominanty w panoramie miasta, a także z powodu wzrostu drzew porastających stok góry, został podwyższony o $180 \mathrm{~cm}$. Uroczystość odsłonięcia zrekonstruowanych krzyży odbyła się 14 czerwca 1989 roku. Aktu poświęcenia odbudowanego od podstaw pomnika dokonał arcybiskup kowieński ks. kardynał Vincentas Sladkevičius?.

$\mathrm{Na}$ terenie dawniej zwanym Altaria Jasińskiego, wchodzącym obecnie w obręb Górnego Parku (Kalný parkas), na prawym brzegu rzeczki Wilenki wznosi się wypiętrzająca się na wysokość 80 metrów góra o stromym, opadającym ku rzece gęsto zalesionym stoku. Góra ta w przeszłości była nazywana Łysą lub Krzywą i niewątpliwie z racji warunków topograficznych należała do miejsc najwcześniej zamieszkałych na terenie Wilna. Niewykluczone, że właśnie na tej górze pierwotnie wznosił się doszczętnie zniszczony przez Krzyżaków w 1390 roku Krzywy zamek, którego śladów poszukiwano także i na sąsiedniej Górze Bekieszowej.

Swoją nazwę „Trzykrzyska” góra ta zawdzięcza temu, że na jej szczycie były od dawna ustawiane trzy krzyże, upamiętniające legendarne męczeństwo w tym miejscu zakonników franciszkańskich. Z męczeństwem tym

5 M. Jackiewicz, Wileński pomnik Trzech Kryysy zostanie wskerzeszony, „Tygodnik Powszechny" 1988 , nr 47, s. 5.

6 A. Srebrakowski, Tray Krayze w Wilnie, „Spotkania z Zabytkami” 1989, nr 6, s. 22.

7 M. Jackiewicz, Wilenska encyklopedia 1939-2005, Warszawa 2007, s. 477.

8 W. Hołubowicz, Krzyny Gród w XIV w. na Górze Bekieszowej w Wilnie, „Wilno” 1939, R. 1, nr 1, s. 27-35, idem, Nowe znalezisko na terenie Krayynego Grodu, „Kurier Wileński” 1939, nr 155 . 
związana jest legenda mówiąca, że niechętni chrystianizacji pogańscy Litwini ukrzyżowali tu siedmiu franciszkanów, a następnie strącili ich w nurt rzeki Wilenki. Legendę tę usiłował uprawdopodobnić Maciej Stryjkowski", odnotowując w swojej kronice, że ów fakt miał miejsce w 1332 roku. Zdaniem jednak zasłużonego badacza historii Litwy, prof. Jerzego Ochmańskiego, „relacje późnych źródeł jakoby za Giedymina wymordowano w Wilnie franciszkanów, a za Olgierda umęczono kilku prawosławnych należą do rzędu legend mających wzmocnić dane wyznanie poprzez szerzenie kultu świętych i męczenników za wiarę"

Powołując się na ustalenia Marcelego Kosmana, Mieczysław Jackiewicz podaje, że wileńscy franciszkanie dla uczczenia pamięci pomordowanych przed wiekami współbraci wznieśli na Górze Krzywej między 1613 a 1636 rokiem trzy drewniane krzyże ${ }^{11}$.

Naprawdę jednak nie wiadomo, kiedy ustawiono drewniane krzyże na szczycie góry, ponieważ pewna informacja źródłowa o tym fakcie pochodzi z 1740 roku. Spopularyzował ja prezes Wileńskiego Towarzystwa Przyjaciół Nauk, ks. prałat Jan Kurczewski, pisząc, że w 1740 roku rozwieszone zostały afisze o treści następującej:

W przyszłą da Pan Bóg niedzielę, to jest 11 września, o godzinie wtorej z południa będa się prowadziły trzy krzyże od kościoła OO. Franciszkanów na Łysą Górę przy procesyonalnej archibractwa Męki Pańskiej i OO. Franciszkanów asystencji na pamiątkę siedmiu Franciszkanów na tej górze za Wiarę Chrystusową Roku 1333 w Miesiąca Marcu pokrzyżowanych. Iść będzie procesya przez Rynek, aby oraz uczyniła pamiątkę iż tam tegoż roku i dnia drogich siedmiu Franciszkanów okrutnie umordowanych za Wiarę Święta pościnano. Na która procesya pomienieni OO. Franciszkanie łask waszych zapraszają - Roku $1740^{12}$.

9 Chodzi tu o dzieło Macieja Stryjkowskiego, „która przedtem nigdy światła nie widziała Kronika polska, litewska, żmudzka i wszelkiej Rusi, Królewiec 1582, cyt. za A. Srebrakowski, op. cit.., s. 19.

10 J. Ochmański, Historia Litwy, Wrocław-Warszawa-Kraków-Gdańsk-Lódź 1982, s. $67-68$.

11 M. Jackiewicz, Wileńska encyklopedia, s. 476.

12 J. Kurczewski, Pamiatka źbudowania i pośniecenia Trzech Krayzón w Wilnie na Górze Traykrsyskiej w roku 1916, Wilno 1916, s. 26-27. 
Następną pewną informację odnoszącą się do trzech krzyży znajdujemy w opracowanym przez Michała Eustachego Brensztejna „Kalendarzu”. „2 lipca 1857 r. (20 VI starego stylu) postawiono nowe Trzy Krzyże drewniane biało pomalowane na miejsce trzech starych"13. Krzyże te dotrwały do 1869 roku, kiedy to zamienily się w próchno ze starości ${ }^{14}$. Ponownego ustawienia krzyży konsekwentnie odmawiali Rosjanie, niechętni zdecydowanie praktykom katolickim ${ }^{15}$. Podjęcie starań o wyrażenie zgody na wzniesienie Trzech Krzyży jako trwałego pomnika na Górze Trzykrzyskiej stało się możliwe dopiero po wejściu do Wilna wojsk niemieckich w 1915 roku. Taka akcję umożliwiła kokietująca Polaków postawa władz wojskowych niemieckich.

Znamiennym tego objawem, jak pisał prof. Konrad Górski, była słynna odezwa ks. Pfeila z dn. 18 września 1915 r. rozlepiona na murach Wilna i wkrótce potem zdzierana przez samych Niemców. Pfeil, zwracając się do ludności wileńskiej w sposób niezwykle ciepły i serdeczny, mówił o Wilnie jako o polskim mieście, które zawsze było perłą w Królestwie Polskim i zakończył oszałamiającym w ustach Niemca zdaniem: Niech Bóg błogosławi Polskę $e^{16}$.

Starając się wykorzystać sprzyjająca chwilowo wileńskim Polakom, lecz jak się okazało krótkotrwałą koniunkturę, Komitet Obywatelski podjął wysiłek ustawienia krzyży na Górze Trzykrzyskiej. Prośbę w tej sprawie, spisaną 26 kwietnia 1916 roku, opatrzona załącznikiem w postaci siedmiu stron podpisów mieszkańców Wilna popierających ten wniosek i dołączoną fotografię modelu pomnika wręczono, jak wynika z odnotowanej na nim daty, 6 maja 1916 roku. Na piśmie tym czytamy:

Nasza ekscelencjo! My niżej podpisani mieszkańcy miasta Wilna mamy honor najpokorniej prosić Waszą Ekscelencję o pozwolenie postawienia na górze Trzykrzyskiej krzyży na pamiątkę OO. Franciszkanów, którzy pierwsi w mie-

13 M. Brensztejn, Porozbiorony Kalendarz. Historyczny Wilna na każdy dzień catego roku zebrał..., Biblioteka Narodowa, Warszawa, Dział Rękopisów I 10643, k. 318.

14 J. Kurczewski, op. cit., s. 27.

15 J. Kłos, Wilno. Prewewodnik krajoznawcsy, Wilno 1937, s. 275.

16 K. Górski, Divide et impera, Białystok 1995, s. 262; niebawem jednak władze niemieckie diametralnie zmieniły swój stosunek do ludności polskiej i zdecydowanie preferowały interesy strony litewskiej. 
ście naszem śmierć za wiarę ponieśli. Wszak wolno czcić ludzi zasłużonych stawianiem pomników, wmurowywaniem pamiątkowych tablic i tak dalej. Jeśli kto, to przede wszystkim ci, którzy za wiarę życie swe ofiarowali zasługuja, by pamięć o nich wśród potomności nie zgasła. Toteż w Wilnie na górze Trzech Krzyży zawsze stały owe pamiątkowe trzy krzyże, które ludność w miarę jak one chyliły się ku upadkowi restaurowała lub całkiem nowemi zamieniała. Czas tylko sprawił, że dziś już owych krzyży nie widzimy. Pomimo niewygód wojennych, pomimo biedy i nędzy pragnęlibyśmy wznieść ową pamiątkę, a może Bóg miłosierny, za wstawiennictwem owych pierwszych męczenników naszych sprawić zachce, że znów pokój zawita do miasta naszego, że ustanie ten straszny przelew krwi, jakiego dziś świadkami jesteśmy. Oczekując łaskawej odpowiedzi i zezwolenia mamy honor załączyć (z prośbą o zwrócenie) fotografię i dokument o wznowieniu krzyży. Wilno 29 kwietnia 1916 r. ${ }^{17}$

Starania komitetu zostały zwieńczone sukcesem. Przebieg przygotowań do realizacji pomnika relacjonuje uczestnik tych działań hr. Wincenty Lubieński.

W dniu 24 czerwca 1916 r. niezwłocznie uformowaliśmy pod egidą J. E. Księdza Administratora Michalkiewicza komitet budowy pomnika nowego Trzech Krzyży w Wilnie. Ze sprawą należało się spieszyć. Zostałem w tym celu zaproszony do mieszkania księdza Administratora na dziś na godzinę piąta po południu. Zebrało się nas mniej więcej szesnastu zaproszonych około dużego stołu w stali mieszkania ks. Michalkiewicza przy ulicy Zamkowej. Byli to: Prezydent miasta Węsławski, wiceprezydent Konrad Niedziałkowski (brat biskupa Żytomiersko-Łuckiego), hr. Sękowski, księża: Kulesza, Lewicki, Kurczewski (historyk), Szudnicki (archeolog i literat), dziennikarz Obst i kilku innych nieznanych $[\ldots]$ Model projektu przedstawiono nam w miniaturze $z$ gliny bielonej pomysłu p. Antoniego Wiwulskiego i bardzo się nam wszystkim podobał oryginalnościa pomysłu. Ze skały wytryskiwały trzy krzyże w kształcie linii harmonijnie obok siebie stojące w grupie. Pomysł trochę moderne. Przystapiliśmy do kosztorysu. P. inżynier Szopa oznaczył nam takowy w kwocie 1300-1500 rubli. Pomnik ma być z betonu i żelaza, wysoki 10 metrów, u spodu 6 metrów szeroki ${ }^{18}$.

17 Lietuvos valstybes istorijas archyvas (LVIA), Litewskie Państwowe Archiwum Historyczne, F. 649, Ap 3B91, L. 26, N. Lukšionyte-Tolvaišienè, op. cit., s. 66.

18 W. Lubieński, Tray Krayze w Wilnie, „Słowo”, Wilno 1937. 
$\mathrm{Na}$ zebraniu tym został też wybrany Komitet Budowy Pomnika Trzech Krzyży. Jego przewodniczącym został ks. Kazimierz Michalkiewicz, a w skład weszli: hr. Wincenty Lubieński, wiceprezydent Wilna Konrad Niedziałkowski i inżynier Teofil Szopa. „Uproszono p. Obsta, dziennikarza o poparcie idei współpracy w prasie wileńskiej”'19.

Dążąc do sprawnego finansowania projektu, inż. Szopa uważał za słuszne rozpropagowanie idei pomnika „wśród ludności miasta, by każda rodzina swoim własnym trudem postarał się fizycznie dopomagać w budowie". Na rozpoczęcie prac ks. Michalkiewicz proponował pożyczkę w wysokości 500 rubli z własnych funduszy. „Dzięki jego inicjatywie, pracy i zapobiegliwości, jak rozpomina Łubieński, wprowadzono w czyn pomysł artysty Wiwulskiego"20.

Jak zanotował pod data 14 lipca 1916 roku w swym „Dzienniku” jeden z członków Komitetu Budowy Pomnika - dr Władysław Zahorski:

Dziennik Wileński otworzył listę składek na budowę [pomnika], składają też Wilnianie ofiary wedle możności po 10, 3, 1 marce, po 50, 25 fenigów. Oprócz tego całe polskie Wilno bierze udział w budowie. Osoby ze wszystkich sfer: panowie, panie, chłopcy, duchowieństwo, rzemieślnicy, szwaczki, sługi, wszyscy noszą na górę żwir, piasek, kamienie, wwożą na wózku cement. Nawet ks. Administrator Michalkiewicz zaprzagł się do wózka. Ja, Hala, sam Wiwulski, jego pomocnik Szopa, oraz kilku panów i panien wwiéliśmy z dołu na sam szczyt góry 10 -pudową beczkę cementu²1 .

Należało spieszyć się z rozpoczęciem prac, gdyż jak słusznie zauważył Łubieński, „akcja nasza polska w grodzie międzynarodowym powaśnionych elementów była solą w oku"22.

W dniu 19 lipca 1916 roku dokonano założenia fundamentów pod nowo powstający pomnik Trzech Krzyży w Wilnie. Wtedy też spisany został po łacinie akt fundacyjny, treść jego w tłumaczeniu na język polski jest następująca:

19 Ibidem.

20 Ibidem.

21 W. Zahorski, Dqiennik [...] z czasón wojny europejskiej 1914-1919, Biblioteka Narodowa, Warszawa, Dział Rękopisów, sygn. II 10457/II, s. 137.

22 W. Lubieński, op. cit., s. 3. 
Na większą chwałę Bożą, na część Jego Świętych Męczenników ku spełnieniu goracych pragnień oraz ku zbawieniu wiecznemu wiernych chrześcijan. Za panowania nad kościołem Chrystusowym papieża Benedykta XV, za rządów diecezji wileńskiej, wobec wygnania biskupa, przez wikariusza i pronotariusza apostolskiego Kazimierza Mikołaja Michalkiewicza zostały założone fundamenty pod budowę trzech krzyży, pod kierownictwem i według pomysłu architekta Antoniego Wiwulskiego i Teofila Szopy przy dobrowolnej pracy i pomocy wiernych chrześcijan na tej górze „Górą Trzykrzyską” już przez naszych pradziadów nazwanej, a to $z$ tego powodu, że za panowania Wielkiego Księcia Litewskiego Olgierda siedmiu braci konwentualnych zakonu św. Franciszka z liczby czternastu braci, jako ofiary w Wilnie zamordowanych przez pogan tu zostali ukrzyżowani. Stąd wdzięczna pamięć tak tych jako i innych pracowników trudniących się od samego wschodzącego na Litwie światła Chrystusowego, oraz zabitych męczenników w ciagu wieku przez chrześcijan $\mathrm{w}$ poświęceniu tych trzech krzyży była czczona $\mathrm{z}$ najgłębszym przejęciem się. Idąc w ślady pobożnych ojców potomkowie wdzięczni w ciężkim czasie szerzącej się na przestrzeni prawie całej Europy najokropniejszej wojny i w naszym też kraju pozbawieni znacznej części ojcowizny i ognisk domowych zarówno w tym mieście uciśnieni i zagrożeni niebezpieczeństwem życia. Wzywający pomocy Bożej ku obronie miasta i pozostałości zniszczonego kraju oraz życia mieszkańców miasta ku przyśpieszeniu zbawiennego pokoju zwrócili usilne prośby do wyżej pomienionego. W.P. Wikarego Apostolskiego, ażeby te krzyże na miejscu dawniejszych, zniszczonych przez starość, zostały wybudowane i poświęcone, obiecując przyłożyć do tego świętego dzieła również swoje pokorne ręce. Że wszystko zostało uczynione zgodnie z życzeniem i wolą wiernych chrześcijan świadczymy i dla tym mocniejszej w to wiary własnoręcznie podpisujemy i stwierdzamy ${ }^{23}$.

Wmurowanie, jak zanotował dr Zahorski, odbyło się w zupełnej cichości, bez aktu uroczystego w obecności ks. Administratora i szczupłego grona osób. $\mathrm{Za}$ trzy tygodnie robota zostanie skończona, formy rozebrane, rusztowania usunięte i nad Wilnem zajaśnieją trzy krzyże jako pamiątka dawnych czasów i pomnik obecnej wojny. W chwili zamurowania puszki rozszalała się burza i padło killka piorunów ${ }^{24}$.

23 W. Zahorski, Dziennik, II, s. 138.

24 Ibidem. 
Ze względu na zły stan zdrowia przy zakładaniu fundamentów pod pomnik Trzech Krzyży nie mógł być obecny jego projektodawca, Antoni Wiwulski, zastępował go współwykonawca dzieła inż. Teofil Szopa. Jednak mimo nieobecności w czasie tej uroczystości autora projektu pomnika zadbano o to, by na akcie fundacyjnym monumentu obok podpisów ks. Michalkiewicza, W. Lubieńskiego, prezydenta i wiceprezydenta Wilna, inż. Szopy, dra Zahorskiego i innych oficjeli znalazł się także podpis Antoniego Wiwulskiego.

Mimo zdecydowanego, wręcz entuzjastycznego poparcia społeczeństwa wileńskiego akcji wzniesienia krzyży, przejawiającego się zarówno w dobrowolnych składkach, zakupie specjalnych cegiełek na budowę, jak i pracy fizycznej, pojawiły się także głosy osób zdecydowanie krytycznie nastawionych do powstającego na Górze Trzykrzyskiej pomnika. Jak odnotował hr. Wincenty Lubieński:

do niezadowolonych z pomysłu budowy pomnika kamiennego na miejscu drewnianych krzyży $\mathrm{i}$ to w dobie dzisiejszej należy między innymi księżna Michałowa Ogińska, która uważa za niewłaściwe odruch ten społeczny za co najmniej nie na czasie i uważa za niewłaściwe, by rozbudzać fantazję głodnych mas nierealnymi pracami pomników, gdy na ulicach mrą rodziny z braku pożywienia, odbierając gotówkę od posiadaczy w imię ideałów narodowych ${ }^{25}$.

Rozpoczęcie budowy krzyży z trwałego materiału spowodowało też protest kilku znanych twórców wileńskich, wśród których prym wiedli popularny malarz i rysownik Stanisław Bohusz Siestrzeńcewicz i ceniony w mieście artysta fotograf Jan Bułhak. Obaj wspomniani twórcy zwrócili się ze zdecydowaną pretensją do Wiwulskiego, że ten

uzurpuje sobie tradycją uświęcone miejsce na górze Trzech Krzyżów na wybudowanie pomnika samowolnego pomysłu, bez niczyjego zezwolenia i autorytetu. Gdy perswazje nie pomogły, a Wiwulski nie zgodził się dobrowolnie zrzec się projektu, postanowili udać się do redakcji Dziennika Wileńskiego z prośbą o umieszczenie na szpaltach tego pisma ich umotywowanego pro-

25 Ibidem. 
testu. Na szczęście, jak trafnie zauważył hr. Łubieński, p. redaktor Obst artykułu nie przyjął do druku, w obawie, aby nie popsuć harmonii różnych jednostek w rozpoczętym dziele pracy pod jednym hasłem, gdyż opozycja łatwo mogła zadać cios całej sprawie ${ }^{26}$.

Odmowa redaktora Obsta zmusiła Bułhaka do wystapienia z listem otwartym, który przesłał zarówno do wszystkich członków Komitetu Budowy Pomnika, jak i do wielu osób zainteresowanych tą akcja. W liście tym jednoznacznie i zdecydowanie potępił pomysł ustawienia betonowych krzyży na szczycie Góry Trzykrzyskiej. List zawiera protest zatytułowany „Trzy Krzyże”, datowany „lipiec 1916 r.”, sygnowany nazwiskiem Jana Bułhaka, dotarł oczywiście także do rąk hrabiego Wincentego Lubieńskiego, jak i samego Wiwulskiego. Chcąc poznać argumentację Bułhaka, należy przytoczyć kilka cytatów z jego listu:

Stały na górze w Wilnie pięć stuleci trzy proste drewniane krzyże. Ilekroć pochyliły ku ziemi zmurszałe ramiona, odnawiała je zawsze ręka troskliwa, by wieczną była męczeństwa pamiątka, by wiecznie jaśniał na Niebie, ponad miastem tryumfujący symbol wiary i narodowości splecionych w nierozerwalne jedno. Przez ostatnie pięćdziesiąt lat krzyże zniknąc musiały i razem z niemi zanikło wiele. I pamięć rzeczy dawnej i sama nazwa góry Trzykrzyskiej, którą zaczęto błędnie utożsamiać z Bekieszowa. Dzisiaj chcą trzy krzyże powrócić na to samo miejsce i po dawnemu objąć na górze nad miastem straż [...] Dawne krzyże były proste, jak prosta wiara dawnych ludzi. Ciosane były z drzew, które wyrosły, nadciosane były dłońmi na pół wiejskich rzemieślników, synów tego miasta - wsi, które zwią Wilno [...] Wyrastały owe krzyże z ziemi samorzutnie niemal, jak te sosny i klony, jak te kwiaty i zioła corocznie ręką wiosny szczodrze rozsiewane [...] Do tego Wilna wracaja na dawne miejsce trzy krzyże. W jakiejże postaci? Żelazno-betonowe z ramionami kształtowanymi stylowo z rzeźbiarską pomnika postawa, ze wszystkimi szczególnymi cechami monumentu. Jest w nich wszystko, co dać może pomnik przemyślany przez utalentowanego artystę. Jednego tylko brak - sielanki, prostoty i harmonii z krajobrazem Wilna. To jest monument, który się zawsze będzie kłócił z krajobrazem i sylwetą góry, dopóki

26 W. Lubieński, op. cit., nr 224, s. 3. 
go ona bogactwem roślinności nie osłoni i nie zwycięży [...] Pomnik obecny pomimo swojej niezaprzeczonej wartości artystycznej jest dla krajobrazu Wilna nieodpowiednim i na górze Trzech Krzyży stanąć nie powinien. Niech o tym pamiętają ci, którzy miast wskrzeszać odwiecznym kształtem nasze wileńskie trzy krzyże, własnoręcznie kopią im grób, a nowym cmentarnym nagrobkiem wołaja: umarly i nie powstaną $a^{27}$.

List Bułhaka doczekał się wcześniej już wspomnianej natychmiastowej odpowiedzi ze strony Łubieńskiego, rozesłanej w formie odezwy do zainteresowanych osób. Czytamy w niej, że

[krzyże] z monolitu betonu i żelaza powstają, powinny przetrwać wieki, by je ani czas, ani wichry wojny, ani ogień, ani złość ludzka nie zniszczyły [...] Nowo powstały pomnik Trzech Krzyży mający na celu podnosić i jednoczyć ducha narodowego i miasto ozdobić, domaga się, by nadać mu zewnętrzną formę trwałego monolitu, wieki przetrwać mogącego; wymaga by zastosować dość nowoczesny modernizm sztuki, odtwarzając jednocześnie tradycję przeszłości i obecne cierpienia narodu i tej potrzeby ekspansji uczuć i czynów. Tym zadaniu zadość czyni świetny pomysł wielkiego artysty p. Antoniego Wiwulskiego, którego budowę na górach świętokrzyskich rozpoczynamy [...] Podobnie i przyszłym pokoleniom milszą będzie każda pamiątka ideologii ducha i sztuki w spuściźnie od nas im pozostawiona, w świadectwie postępu i ewolucji. Cenniejsze może staną się im te symbole pracy i nadziei, w betonie i żelazie przetrwałe, jak resztki spróchniałych drzew z drzewa wznowionych krzyżów ${ }^{28}$.

Swoją replikę Łubieński najpierw pokazał Wiwulskiemu, a ten z wdzięcznościa zaaprobował wyrażone w niej stanowisko. Wiwulski zaś w odpowiedzi Bułhakowi przestał list następującej treści:

Drogi Panie Janie! Poetyczny, szczery i piękny pański protest, czy też zupełnie słuszny, otóż mnie się zdaje, że nie! Niesłusznym z dwóch powodów. Prawda, że Wilno jest obecnie wsia, że jest sielskie, ale w każdym razie to miasto i w punkcie ważnym i miasto przyszłości, a więc rozszerzające się i zwiększające i już teraz jego mieszkańcy widzą szereg ulic tam, gdzie przedtem by-

27 Ibidem.

28 Ibidem. 
ły pola i lasy, a teraz miejska młodzież ujrzy nową postać miasta. To jest koniecznością i nic w tym nie zmienimy. Kto wie czy na góry okoliczne z czasem nie siąda pałace i wille, zatem białe jak kościoły Wilna krzyże, niewiele uszczerbku przyniosa sielskiemu krajobrazowi. Przeciwnie, może go ochronią, bo - i tu drugi powód ich stawiania, nadadzą tej górze religijna pamiątkę piękna i oddala tym samym zakusy możliwe później, by się tam pobudować. Od czasu naszej rozmowy oglądałem z daleka to miejsce $z$ wieży rusztowań i z różnych ulic i doszedłem do wniosku, że nie oszpecą one Wilna, gdyż plama ich niewiele będzie się różnić od plamy, jaką dałaby biała murowana kapliczka, a wszakże nigdy jeszcze prosta kapliczka lub kościółek nie szpeciły żadnej góry. Naturalnie, że drewniane krzyże więcej się stosują do pejzażu, tak jak słomiana strzecha więcej jak dachówka lub dach z miedzi, ale nie sposób dlatego wyrzekać się postępu i przenosić rzeczy nietrwałe, chwilowe, nad długowieczne silne. Jesteśmy narodem walczącym, gnębionym, wiara nasza też ciagle jest atakowana, zatem przede wszystkim... silnie idzie naprzód, a nie ciagle patrzymy w tył w tradycję. Bądźmy młodzi, rzutni, jak nasz naród huczny, butny, jak para mazura prąca naprzód. Komponowałem te krzyże z zapałem i nie sądzę, że zrobią one coś złego, a że poruszyły umysły pro i contra, to i dobrze, bo i to jest życie, ruch. Pewny też jestem, że gdy staną, znajdzie Pan momenty i miejsca, z których potrafi Pan zrobić śliczne zdjęcia i wzbogacić swą piękną kolekcję, naturalnie o ile Pan się nie uprze, ale do takich Pana nie zaliczam. Ściskam dłoń Pańska. Antoni Wiwulskii ${ }^{29}$

Koncepcja zaprojektowanego przez Wiwulskiego pomnika i zamysł wykonania go w żelbecie dawało twórcy możliwość operowania dowolnymi kształtami i rozmiarami. Przedstawiała się zaś następująco: na wspólnym wysokim cokole, nieco wysuniętym do przodu, pod środkowym krzyżem i cofającym się po łuku ku bokom wzniesione zostały dwa pozostałe krzyże, wszystkie odlane z tej samej formy. Ich krawędzie od strony frontowej, skierowanej ku miastu, podkreśla wąska listwa. Ograniczona listwą część środkowa pionowej belki wklęsła u góry uwypukla się ku środkowi. Przecięcie ramion dodatkowo zostało zaakcentowane czterema plastycznie opracowanymi guzami, które kształtem przypominaja główki kutych gwoździ. W ten sposób uzyskał twórca tak ważną w wypadku dzieła

29 Ibidem. 
rzeźbiarskiego możliwość dodatkowych efektów światłocieniowych. W pomniku wzniesionym na Górze Trzykrzyskiej, podobnie jak i w innych projektach Wiwulskiego, znalazły wyjście dwie pasje artystyczne tego twórcy: architektura i rzeźba. „Stąd, jak trafnie odnotował Krzysztof Stefański, rzeźbiarska dynamika form $\mathrm{w}$ dziełach architektonicznych i architektonicz-

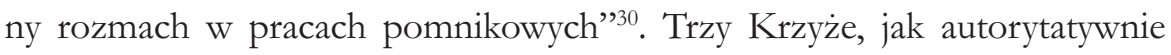
stwierdził ks. Walerian Meysztowicz „były już dziełem dojrzałego talentu”31.

Wileński pomnik Trzech Krzyży słusznie został „uznany za jedno z najpiękniejszych dzieł modernizmu europejskiego, rzeczywiście wydawał się piękny” i stanowił, jak pisze Elżbieta Sawicka, „potężny żelazobetonowy monolit”32. Przekonanie o jego trwałości i niezniszczalności okazało się jednak niestety złudne, ponieważ komunistyczne władze Litwy radzieckiej, przygotowując się do zapowiedzianej wizyty w Wilnie ministra spraw zagranicznych ZSRR Wiaczesława Mołotowa, obawiając się jego reakcji na tak wyraźnie wyeksponowany symbol religijny w panoramie miasta, najprawdopodobniej chcąc uniknąć oskarżeń o hołdowanie „religijnemu zacofaniu" w ateistycznym radzieckim społeczeństwie, podjęły decyzję o usunięciu krzyży. Do ich zniszczenia musiano użyć znacznej ilości materiałów wybuchowych, gdyż konstrukcja pomnika, wykonana przez inżyniera Teofila Szope, była na tyle trwała i mocna, że krzyże nie dały się zniszczyć całkowicie, o czym świadczą zachowane i eksponowane obecnie ich fragmenty, widniejące obok zrekonstruowanego pomnika. Bezpośrednio po wysadzeniu w powietrze pozostałe fragmenty pomnika zostały częściowo usunięte z terenu góry, częściowo pokryte na miejscu grubą warstwą ziemi. Planowana inspekcja z Moskwy nie doszła w końcu do skutku, natomiast krzyże znikły z powierzchni ziemi na całe trzydzieści dziewięć lat. Dopiero rozpad Zwiazku Radzieckiego i w jego konsekwencji powstanie niepodległej Litwy umożliwiły działania mające na celu odbudowę pomnika Trzech Krzyży. Trudną do przecenienia rolę w tym dziele odegrał litewski architekt Henrikas Šilgalis, który na podstawie dawnych zdjęć i pomiarów od-

30 K. Stefański, Antoni Wimulski jako architek.t, „Biuletyn Historii Sztuki” R. 56: 1994, nr $1-2$, s. 67.

31 W. Meysztowicz, Gawedy o czasach i ludziach, Londyn-Lomianki 2008, s. 235.

32 E. Sawicka, Powrót Trzech Krayysyy, „Lituania” 1991, nr 1, s. 33. 
kopanych fragmentów, ponieważ projekt autorski z 1916 roku się nie zachował, opracował plan pomnika całkowicie zgodny z koncepcja Wiwulskiego. Prace rzeźbiarskie przy pomniku wykonał w ciagu dwóch tygodni znany litewski artysta rzeźbiarz Stanislowas Kuzma ${ }^{33}$.

Bezsprzecznym osiagnięciem Šilgalisa i Kuzmy jest fakt, że nowe krzyże są takie same jak te wykonane w 1916 roku, tylko o prawie 2 metry wyższe i znacznie bielsze. Zasługa tych twórców polega również na tym, że nie silili się na „poprawienie i ulepszenie” koncepcji Wiwulskiego. Byli na tyle wierni pierwowzorowi, że nawet powtórzyli majuskułowy napis fundacyjny na frontowej stronie cokołu środkowego krzyża, dodając do daty wzniesienia pomnika 1916 roku daty jego zniszczenia 1950 i odbudowy 1989. Na wieść o rekonstrukcji pomnika Trzech Krzyży, silnie związany z tym miastem jako konserwator okręgowy w międzywojennym dwudziestoleciu, prof. Stanisław Lorentz napisał: „Panorama Wilna została dopełniona, odzyskała jeden z dominujących akcentów"34. A Tomas Venclova, w pełni doceniając znaczenie tego pomnika w panoramie Wilna, trafnie zauważył, że „Wiwulski pozostawił swój ślad w wileńskim krajobrazie - między górą Zamkową a Bekieszowa postawił trzy betonowe krzyże, które dla Wilna znaczą mniej więcej tyle co posag Chrystusa wieńczący Rio de Janeiro”35.

\section{Summary}

\section{The Three Crosses of Vilnius}

This article relates the history of the monument known as Three Crosses, designed by Antoni Wiwiulski and built with the participation of the citizens of Vilnius

33 Stanislowas Kuzma uznawany za jednego z wybitniejszych współczesnych rzeźbiarzy litewskich, urodzony w 1947 r. w Poniewieżu, absolwent Akademii Sztuk Pięknych w Wilnie, autor wielu realizacji, takich jak np. „Lato” (1974), „Źródło” (1981), „Święto Muz” na fasadzie teatru w Wilnie (1981), „Pieta” na cmentarzu Antokolskim na grobach obrońców wieży telewizyjnej w Wilnie (1995), obok wspomnianej rekonstrukcji Trzech Krzyży Wiwulskiego wykonał także repliki postaci świętych Stanisława, Heleny i Kazimierza zdobiące fronton fasady katedry wileńskiej, por. M. Jackiewicz, Wileńska encyklopedia, s. 327.

34 S. Lorentz, Moja wizja Wilna. Wilno i Wileńszcsyzna jako krajobraz i środowisko wielu kultur, red. E. Felisiak, t. 1, Białystok 1992, s. 25.

35 T. Venclova, Opisać Wilno, Warszawa 2006, s. 244. 
in 1916 as a reinforced concrete construction. Occupying a dominant position in the city panorama, it was blown up in May 1950 by the Lithuanian communist authorities. When Lithuania regained its independence in 1989, the monument was reconstructed by the architect Henrikas Silgaris in collaboration with the sculptor Stanislovas Kuzma. 
[178]

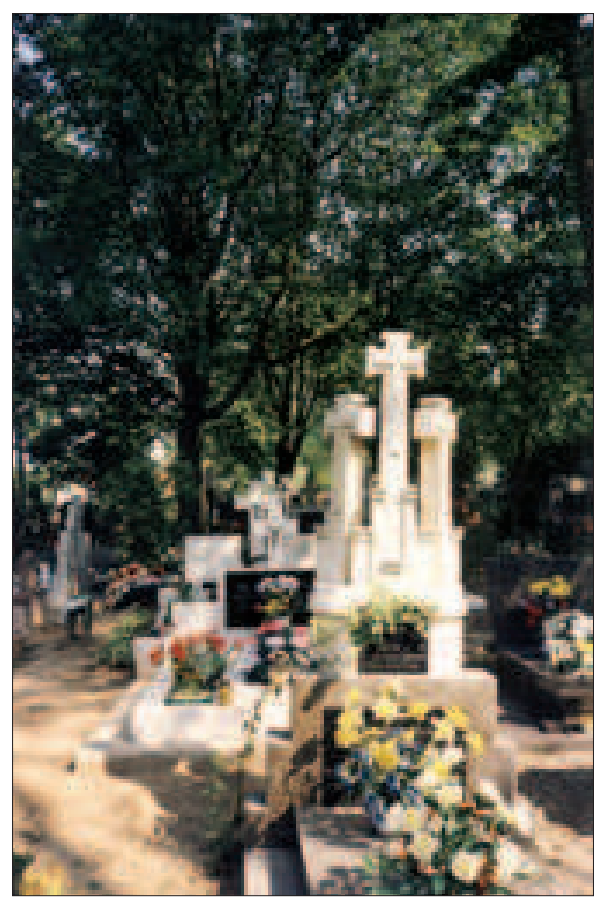

Il. 1. Nagrobek Michaliny Najworsz (1900-1983) na cmentarzu komunalnym w Giżycku, fot. J. Poklewski

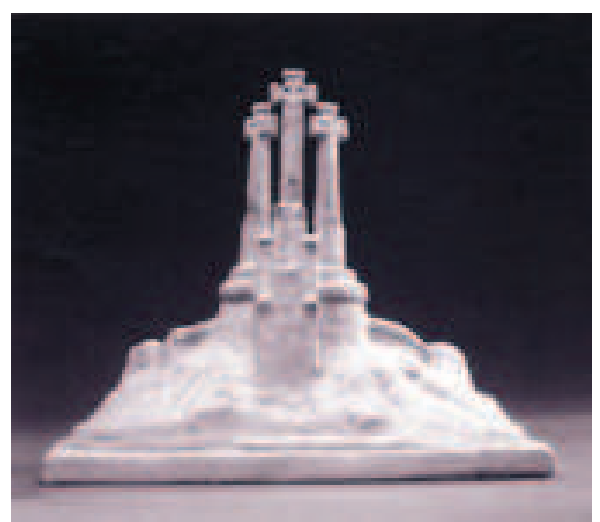

Il. 2. Antoni Wiwulski, Model pomnika Trzech Krzyży w Wilnie 1916, fot. ze zbioru autora 


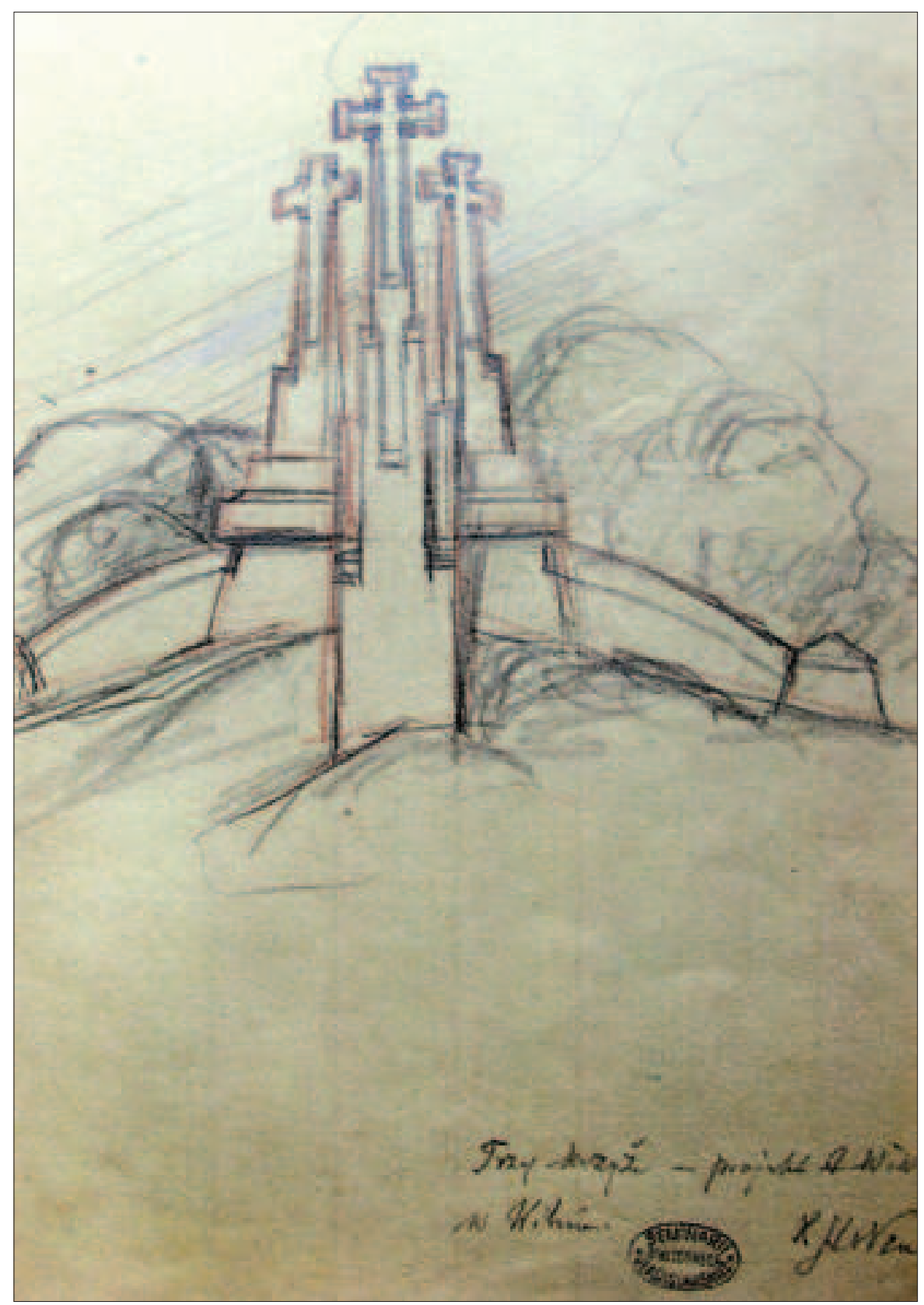

Il. 3. Antoni Wiwulski, Pomnik Trzech Krzyży w Wilnie - rysunek ze zbiorów Biblioteki Seminarium Duchownego we Włocławku, fot. A. Skowroński 


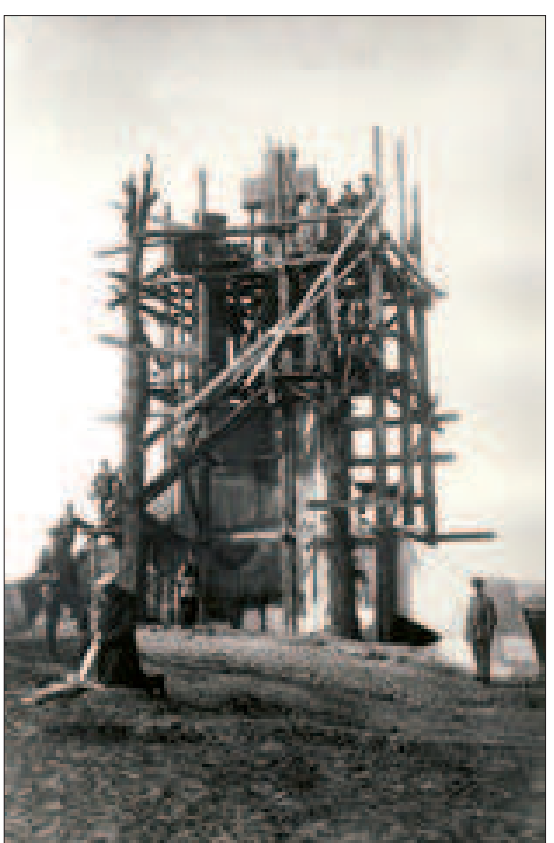

Il. 4. Budowa Trzech Krzyży, Wilno 1916, fot. W. Zahorski, ze zbioru autora

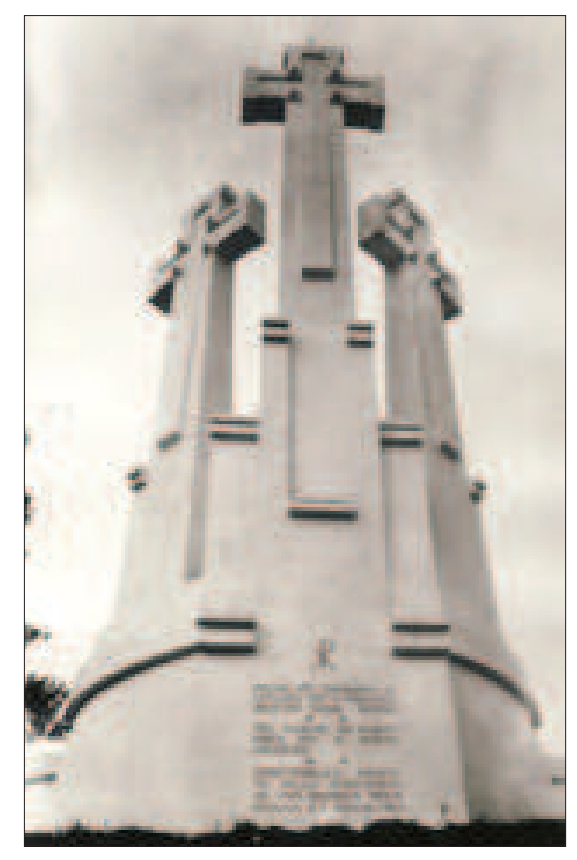

Il. 5. Antoni Wiwulski, Trzy Krzyże w Wilnie 1916, fot. W. Zahorski, ze zbioru autora

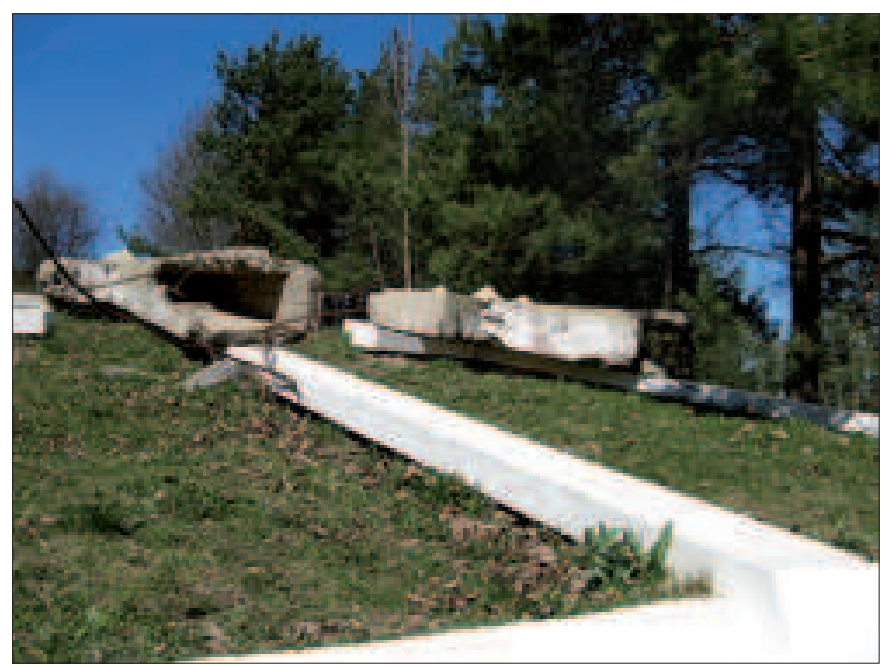

Il. 6. Zniszczone Krzyże Wiwulskiego, fot. A. Mosingiewicz 


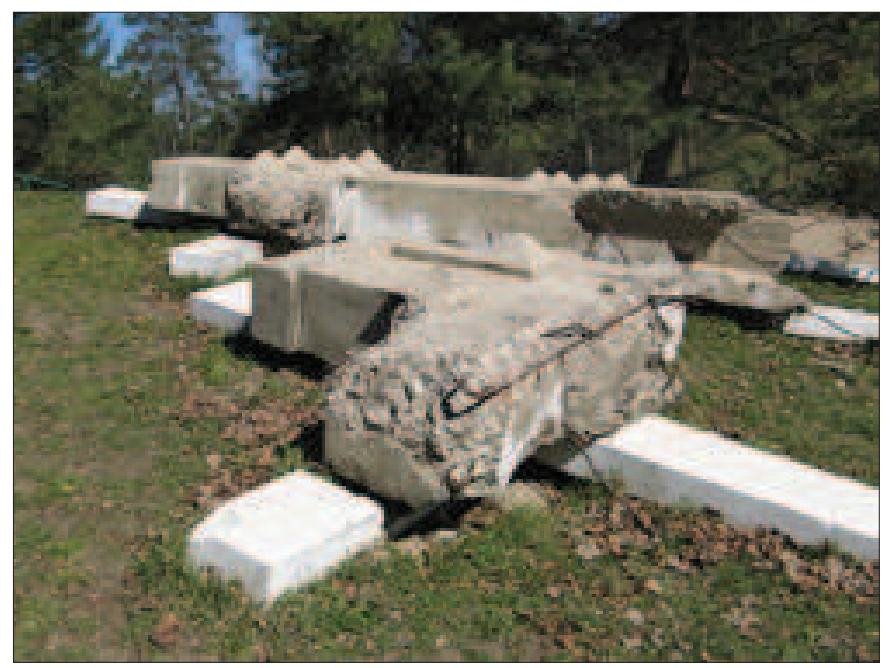

Il. 7. Zniszczone Krzyże Wiwulskiego, fot. A. Mosingiewicz

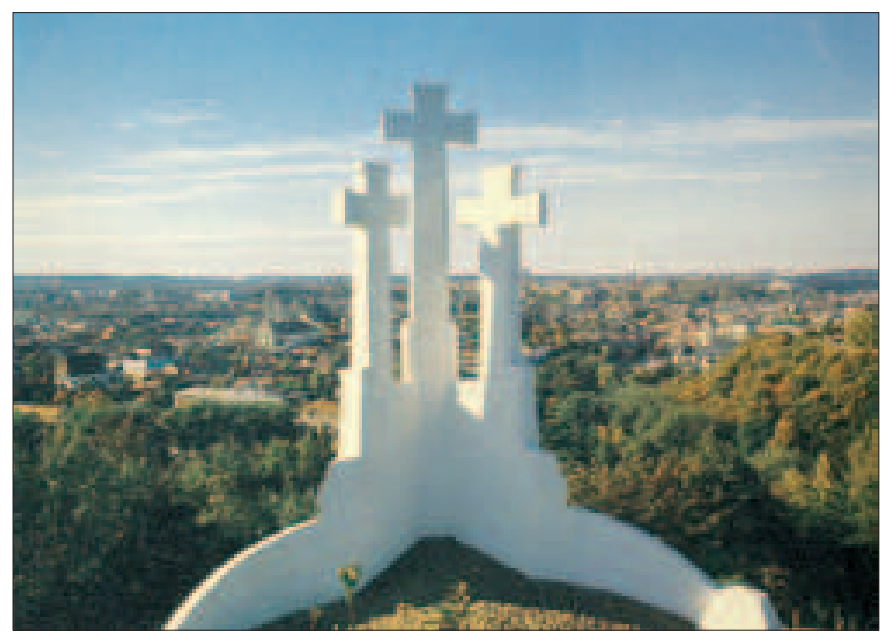

Il. 8. Odbudowane Krzyże na tle panoramy Wilna, fot. J. Polio, ze zbioru autora 
[182]

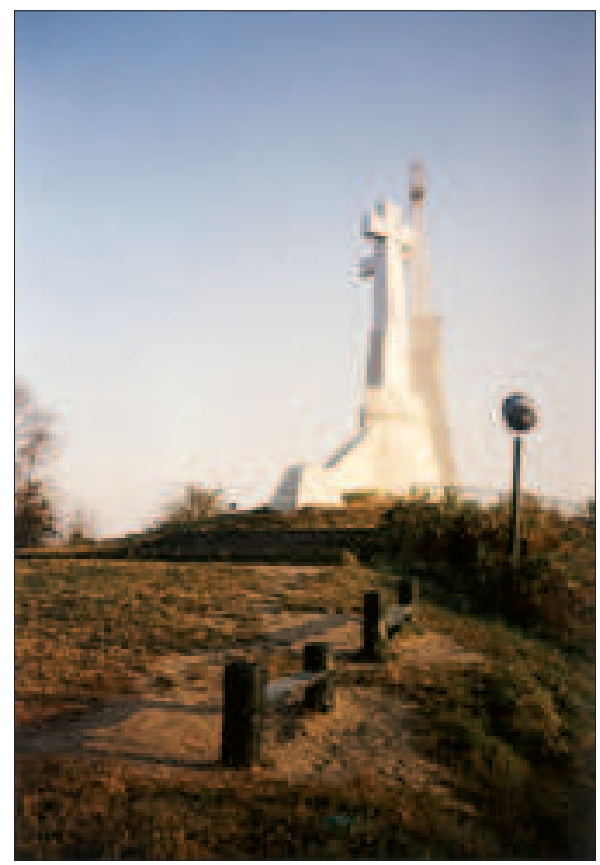

Il. 9. Odbudowane Trzy Krzyże, widok z boku, fot. J. Poklewski

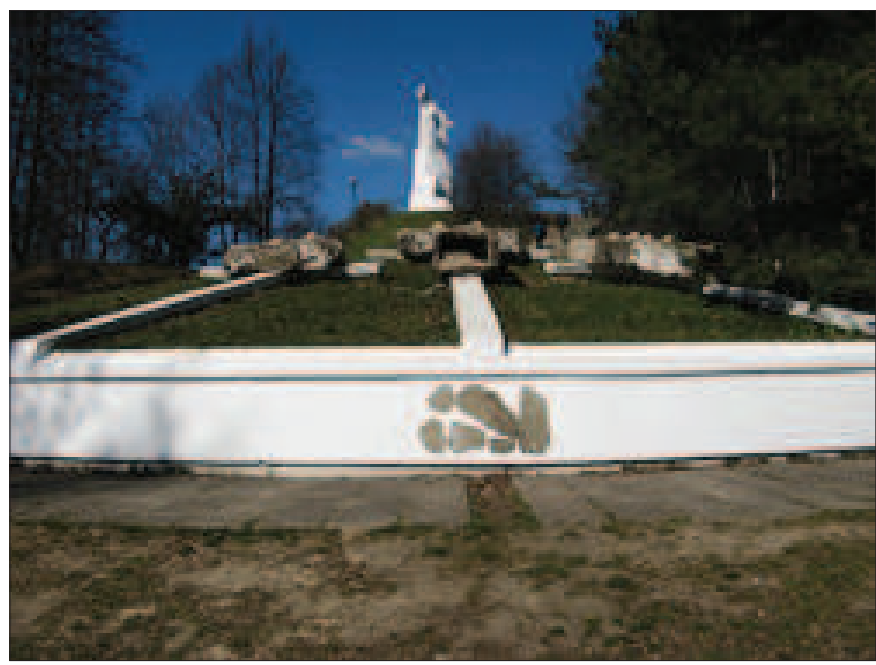

Il. 10. Trzy Krzyże odbudowane i zniszczone, fot. A. Mosingiewicz 